\title{
Penerapan Nilai-nilai Ajaran Islam dalam Kehidupan Masyarakat Di Desa Garuntungan Kecamatan Kindang Kabupaten Bulukumba
}

\author{
Samhi Muawan Djamal \\ samhimuawandjamal@gmail.com \\ Universitas Islam Negeri (UIN) Alauddin Makassar
}

\begin{abstract}
This study aims to observe, to describe the implementation of Islamic teaching in the life of Garuntungan Village, District Kindang Bulukumba and to explain the factors that affect the implementation of teaching and practice of Islamic values in the community. The result of the research shows that Islamic teaching is basically practiced by people of Garuntungan village, although this practice is limited to formal religious rituals. Deep and well understanding of Islamic teaching is not implemented well in their private life, family, and society. This condition is supported by several factors such as the shifting behavior of society in the implementing the values of Islamic teachings, environment, community affair, lack of Islamic promulgation (da'wah), lack of parental knowledge of Islam, and community's less interest in pursuing education but seeking job for earning money.
\end{abstract}

Keywords: Islamic teaching, education, behavior, implementation.

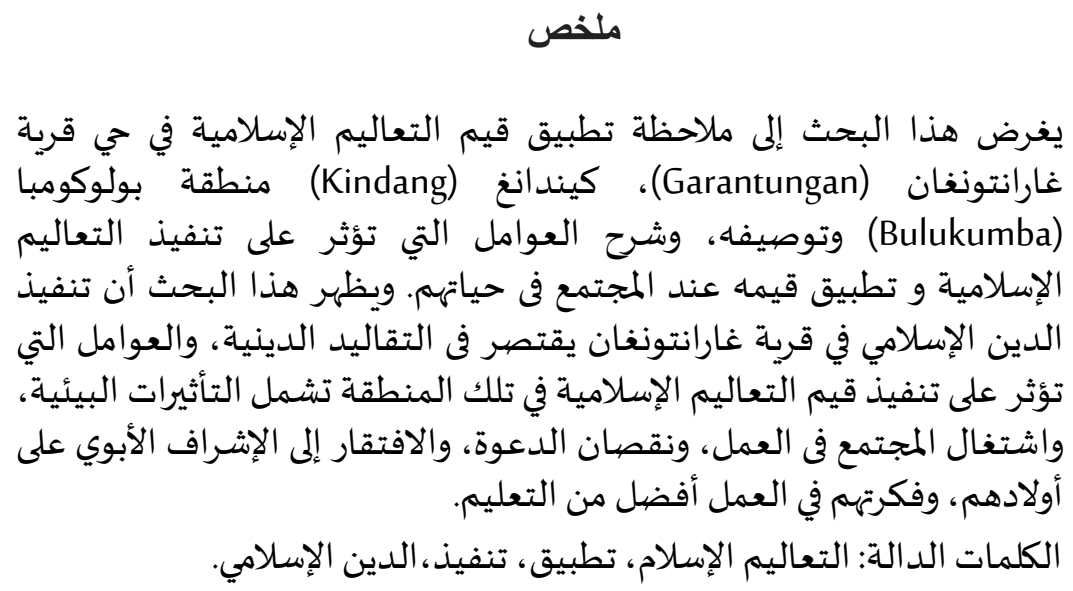




\begin{abstract}
Abstrak
Penelitian ini mengamati dan mendeskripsikan penerapan nialinilai ajaran Islam dalam kehidupan Masyarakat Desa Garuntungan Kecamatan Kindang Kabupaten Bulukumba serta menjelaskan faktor yang memengaruhi pelaksanaan ajaran dan pengamalan nilai-nilai Islam dalam masyarakat tersebut. Hasil penelitian menunjukkan bahwa pelaksanaan ajaran agama Islam masyarakat Desa Garuntungan pada dasarnya berjalan, walaupun sebatas pada ritual-ritual atau tradisi keagamaan, sementara nilainilai ajaran Islam tidak terimplementasi dengan baik dalam kehidupan pribadi, keluarga, dan masyarakat. Adapun beberapa faktor yang memengaruhi terjadinya pergeseran perilaku masyarakat dalam pelaksanaan nilai-nilai ajaran Islam di Desa Garuntungan Kecamatan Kindang Kabupaten Bulukumba meliputi pengaruh lingkungan, kesibukan masyarakat, kurangnya siraman rohani (intensitas dakwah), kurangnya pengawasan orang tua terhadap anak, dan pemikiran masyarakat yang lebih mementingkan mencari kerja dibanding menempuh pendidikan.
\end{abstract}

Kata kunci: Ajaran Islam, pemahaman agama, Desa Garuntungan

\title{
A. Pendahuluan
}

Umat Islam merupakan manusia yang meyakini Islam sebagai agama dan kepercayaan. Agama Islam memiliki konsepsi keyakanin, tata-aturan, norma-norma atau etik yang harus diyakini dan dilaksanakan oleh penganutnya secara konsekwen.

Islam diyakini sebagai agama yang sempurna, bukan saja karena tuntunannya yang serba mencakup seluruh segmen kehidupan manusia, tetapi juga memiliki aturan yang berfungsi mengontrol dan mengawasi bahkan memberi penghargaan dan sanksi. Oleh karena itu, selayaknya umat Islam mengamalkan ajaran agamanya dengan saksama dan konsisten demi mencapai kualitas hidup yang sejahtera di dunia dan di akhirat.

Umat Islam dalam menjalankan agamanya membutuhkan pendidikan dan pengajaran. Pendidikan merupakan salah satu cara untuk meningkatkan kualitas sumber daya manusia, bahkan pada dasarnya, kemajuan pendidikan adalah sesuatu yang menjadi target utama seluruh bangsa. Dengan demikian, pendidikan mendapat perhatian khusus dalam sebuah masyarakat modern.

Masyarakat Indonesia yang mayoritasnya menganut agama Islam menyadari akan hal tersebut, sehingga ketika Indonesia menjadi negara berdaulat dan modern, prioritas utama adalah investasi human skill dengan cara membentuk silabus pendidikan secara sistematis.

Pendidikan seharusnya berorientasi kepada pengenalan realitas diri manusia dan dirinya sendiri. Pengenalan itu tidak cukup hanya bersifat objektif atau subjektif, tetapi harus kedua-duanya. Kebutuhan objektif untuk mengubah keadaan yang tidak manusiawi selalu memerlukan kemampuan subjektif (kesadaran subjektif), objek, dan 
pendidikan adalah realitas keluarga, sedangkan peserta didik dan pendidik sama-sama menjadi subjek atau pelaku.

Adapun tujuan pendidikan Islam yang lebih komprehensif yaitu untuk mencapai pertumbuhan kepribadian manusia yang menyeluruh secara seimbang melalui latihan jiwa, intelektual, diri manusia yang rasional, perasaan, dan indera. Oleh karena itu, pendidikan harus mencapai pertumbuhan manusia dalam segala aspeknya, baik spiritual, intelektual, imajinatif, fisik, ilmiah, bahasa, secara individu maupun kolektif, serta mendorong semua aspek ini ke arah kebaikan dan mencapai kesempurnaan. Tujuan akhir pendidikan Islam terletak dalam perwujudan ketertundukan yang sempurna kepada Allah swt., baik secara pribadi, komunitas, maupun seluruh umat manusia. ${ }^{1}$

Berdasarkan pemaparan di atas, maka benang merah yang dapat ditarik bahwa pendidikan merupakan suatu media dan aktivitas membangun kesadaran kritis, kedewasaan, dan kemandirian peserta didiknya. Pendidikan yang ditempuh oleh seorang individu tentu saja dipengaruhi oleh faktor kehidupan keluarga dan masyarakat sekitar. Melalui proses pendidikan diharapkan mampu menciptakan mentalitas dan kultur pendidikan keluarga. ${ }^{2}$

Dalam konteks desentralisasi pendidikan yang tertuang melalui otonomi pendidikan, bahwa pertama, memberikan kebebasan seluas-luasnya kepada keluarga dalam iklim Laissez Faire (keseimbangan). Pemerintah membuka kepada keluarga untuk melibatkan diri dalam berbagai bentuk pendidikan tanpa ada campur tangan atau kontrol pemerintah. Kedua, melakukan pengaturan ketertiban keluarga dalam pendidikan. Ketiga, memberikan subsidi dan dukungan. Keempat, reformasi aturan. ${ }^{3}$ Tujuan pendidikan dalam keluarga ini tidak dapat terwujud apabila kesadaran keluarga akan pentingnya pendidikan masih rendah.

Kesadaran untuk menempuh pendidikan tidak terlepas dari pengetahuan serta pemahaman agama yang utuh, karena dibutuhkan kesadaran serta semangat yang besar untuk terus belajar mencari ilmu. Pendidikan tidak hanya diperoleh di lembaga formal, tetapi juga informal, karena keluarga membangun perubahan dan berpartisipasi aktif di dalamnya, sehingga manusia dapat dibentuk menjadi makhluk moral spiritual (moral-spiritual-being), agar menjadi lebih baik dan bertaqwa kepada sang pencipta. ${ }^{4}$

Pemahaman agama dapat dilihat dalam kehidupan keluarga yang masih awam dengan kehidupan tradisional, baik dari segi aspek intensitas keberagamaan yang dimiliki masih awam, cara atau metode dalam beragama lebih menekankan pada aspek emosional, serta pola perilaku beragamanya cenderung pada kelakuan lahiriyah (eksoteris) dan sikap dalam beragama kental dengan nuansa trandisional.

Faktor penyebab tingkat pemahaman agama seseorang dapat dipengaruhi oleh beberapa faktor, yaitu dari luar dan dari dalam. Dari luar, di antaranya ekonomi, sosial, politik, dan budaya. Dari dalam, di antaranya dangkalnya ilmu pengetahuan agama, malas beribadah, dan sebagainya. Lebih-lebih faktor dari luar yang kadang sangat mempengaruhinya, sehingga sebuah keluarga lebih mementingkan hal-hal yang bersifat materi daripada hal-hal yang bersifat transendental. Kesibukan yang 
dilakukan untuk memenuhi kebutuhan sehari-hari menyebabkan waktu yang dimiliki terkuras habis untuk mencari materi dan kesempatan mempelajari agama kurang, sehingga pemahaman agama mereka lebih bersifat paternalistik (mengandalkan pada figur atau tokoh kunci). ${ }^{5}$

Pemahaman agama juga disebabkan budaya yang mengangkat pada keluarga setempat, yaitu peran orang tua memberikan kesempatan kepada kaum muda belajar, namun mereka berpendapat bahwa semakin banyak orang yang pintar, maka akan menghilangkan budaya setempat. Misalnya yang dialami oleh keluarga Samin, orang tua mereka menyuruh anak-anaknya sekolah dan menjalankan ibadah agama dengan baik, namun anak-anaknya tidak bersedia menjalankan, hal ini ada dan benar-benar terjadi.

Pemahaman agama sebagian besar keluarga yang ada di Desa Garuntungan Kecamatan Kindang Kabupaten Bulukumba terlihat masih minim, atau terlihat kurangnya pemahaman agama secara utuh, sehingga menimbulkan berbagai macam hal yang merugikan bagi keluarga itu sendiri maupun masyarakat sekitarnya. Masih banyak keluarga masyarakat yang jarang melaksanakan shalat, malas untuk shalat berjamaah di masjid, tidak aktif dalam pengajian, suka berbuat hal-hal yang merugikan orang lain, tidak mau bersedekah, dan sebagainya. Oleh karena itu, keluarga masyarakat yang ada di Desa Garuntungan Kecamatan Kindang menjadi resah akan segala tindakan yang dilakukan oleh orang-orang yang demikian.

Pemahaman agama yang minim berdampak pada rendahnya pemahaman akan pentingnya ilmu pengetahuan dan kurangnya penyiapan kader yang berkualitas. Peluang untuk mengenyam pendidikan yang begitu sempit ditambah dengan pengetahuan agama keluarga yang minim menyebabkan kesadaran keluarga rendah dalam bidang pendidikan. Apalagi kondisi ekonomi keluarga yang ada di Desa Garuntungan merupakan golongan ekonomi menengah ke bawah, sehingga tidak mampu menyekolahkan anaknya karena biaya sekolah yang begitu mahal. Proses pendidikan yang berjalan seadanya menyebabakan minimnya kesadaran untuk berkembang atau melakukan perubahan.

Keluarga sangat berperan atau menjadi subjek dalam memberikan atau menanamkan kebiasaan pada anak dengan cara yang baik menurut ajaran agama Islam, karena menurut fungsinya keluarga merupakan sarana pendidikan yang pertama kali sebelum anak memasuki remaja. ${ }^{6}$ Fungsi keluarga sangatlah penting dalam proses pendidikan karena fungsi keluarga sebagai lembaga pendidikan pertama dan utama yaitu menjadi tempat persemaian pembentukan/penanaman kebiasaan bagi seorang anak. Adapun yang berperan aktif dalam keluarga yaitu ibu, ayah, anggota keluarga lain, serta diri mereka sendiri, yang merupakan kunci pendorong agar anak rajin dalam menuntut ilmu, baik ilmu umum maupun ilmu agama.

Penanaman nilai-nilai sosial serta nilai-nilai ajaran agama juga dimulai dari peran serta keluarga. Pada usia dini, keluarga yang memiliki pemahaman agama yang baik tentu akan mewariskan pemahaman agama tersebut kepada keturunan mereka melalui penanaman nilai-nilai agama yang termasuk dalam rukun iman serta rukun Islam serta pengamalannya, sehingga seiring pertumbuhan anak, penanaman nilai tersebut akan tumbuh menjadi sutu kebiasaan yang pada akhirnya menjadi sebuah 
kewajiban bagi dirinya, sehingga timbul kesadaran penuh untuk menjalankan perintah agama serta menjauhi segala larangan agama. Pada saat anak tumbuh menjadi dewasa penanaman nilai-nilai agama tersebut akan terwujud dalam pelaksanaan dalam kehidupan sehari-hari.

Pemahaman agama terutama pada keluarga yang hidup di pedesaan yang sulit menerima perubahan dalam bidang pendidikan serta sikap acuh tak acuh yang mereka miliki terhadap perkembangan dunia pendidikan menyebabkan penulis tertarik untuk mengadakan penelitian mengenai hal tersebut. Pemahaman agama tersebut dapat terlihat dari aplikasi serta pelaksanaan ajaran agama Islam dalam kehidupan keluarga serta kehidupan bermasyarakat tentunya. Adapun topik penelitian yang akan dikaji dalam penelitian ini adalah "Pelaksanaan Nilai-Nilai Ajaran Islam dalam Kehidupan Masyarakat di Desa Garuntungan Kecamatan Kindang Kabupaten Bulukumba". Masalah yang akan dikaji dalam penelitian ini, antara lain: (1) Bagaimana gambaran pemahaman serta pelaksanaan nilai-nilai ajaran agama Islam dalam kehidupan masyarakat di Desa Garuntungan Kecamatan Kindang Kabupaten Bulukumba?, (2) Bagaimana keterkaitan antara pemahaman nilai-nilai ajaran Islam dengan pelaksanaan nilai-nilai ajaran Islam dalam kehidupan masyarakat di Desa Garuntungan Kecamatan Kindang Kabupaten Bulukumba?

\section{B. Metode Penelitian}

Penelitian ini menggunakan pendekatan penelitian deskriptif kualitatif. Penelitian kualitatif adalah penelitian yang menghasilkan data deskripsi, baik ucapan maupun tulisan dan perilaku yang dapat diambil dari orang-orang atau subjek itu sendiri. Jadi, penelitian kualitatif adalah prosedur penelitian yang menghasilkan data deskriptif berupa kata-kata tertulis atau lisan dari orang-orang dan perilaku yang dapat diamati. $^{7}$

\section{Lokasi dan Waktu Penelitian}

Penelitian ini dilaksanakan di Desa Garuntungan Kecamatan Kindang Kabupaten Bulukumba. Pemilihan lokasi penelitian didasarkan pada pertimbangan bahwa daerah tersebut secara keseluruhan warganya beragama Islam, namun masih perlu pendalaman tingkat pemahamannya tentang ajaran Islam. Penelitian ini dilaksanakan selama 3 (tiga) bulan.

\section{Konsep Pemahaman Agama Islam}

\section{Pengertian Pemahaman Agama}

Menurut Poerwadarminta, pemahaman merupakan proses berpikir dan belajar. Dikatakan demikian, karena untuk menuju ke arah pemahaman perlu diikuti dengan belajar dan berpikir. ${ }^{8}$ Sedangkan Purwanto mengemukakan bahwa pemahaman merupakan proses, perbuatan dan cara memahami atau mendefinisikan. ${ }^{9}$ Oleh karena itu, pemahaman diartikan sebagai tingkatan kemampuan yang mengharapkan seseorang mampu memahami arti atau konsep, situasi, serta fakta yang diketahuinya. Dalam hal ini ia tidak hanya hafal secara verbalitas, tetapi memahami konsep dari masalah atau fakta yang ditanyakan, 
maka operasionalnya dapat membedakan, mengubah, mempersiapkan, menyajikan, mengatur, menginterpretasikan, menjelaskan, mendemonstrasikan, memberi contoh, memperkirakan, menentukan, dan mengambil keputusan. Di dalam ranah kognitif menunjukkan tingkatan-tingkatan kemampuan yang dicapai dari yang terendah sampai yang tertinggi. Dapat dikatakan bahwa pemahaman tingkatannya lebih tinggi dari sekedar pengetahuan.

Definisi pemahaman menurut Sudijono adalah kemampuan seseorang untuk mengerti atau memahami sesuatu setelah sesuatu itu diketahui dan diingat. ${ }^{10}$ Dengan kata lain, memahami adalah mengetahui tentang sesuatu dan dapat melihatnya dari berbagai segi. Pemahaman merupakan jenjang kemampuan berpikir yang setingkat lebih tinggi dari ingatan dan hafalan.

Menurut Azwar, dengan memahami berarti sanggup menjelaskan, mengklasifikasikan, mengikhtisarkan, meramalkan, dan membedakan. ${ }^{11}$ Sedangkan menurut Winkel, yang dimaksud dengan pemahaman adalah mencakup kemampuan untuk menangkap makna dan arti dari bahan yang dipelajari. ${ }^{12}$ Adanya kemampuan ini dinyatakan dalam menguraikan isi pokok dari suatu bacaan, mengubah data yang disajikan dalam bentuk tertentu ke bentuk lain, seperti rumus matematika ke dalam bentuk kata-kata, serta membuat perkiraan tentang kecenderungan yang nampak dalam data tertentu, seperti dalam grafik.

Berdasarkan berbagai pendapat di atas, indikator pemahaman pada dasarnya sama, yaitu dengan memahami sesuatu berarti seseorang dapat mempertahankan, membedakan, menduga, menerangkan, menafsirkan, memperkirakan, menentukan, memperluas, menyimpulkan, menganalisis, memberi contoh, menuliskan kembali, mengklasifikasikan, dan mengikhtisarkan. Indikator tersebut menunjukkan bahwa pemahaman mengandung makna lebih luas atau lebih dalam dari pengetahuan.

Melalui pengetahuan, seseorang belum tentu memahami sesuatu yang dimaksud secara mendalam, hanya sekedar mengetahui tanpa bisa menangkap makna dan arti dari sesuatu yang dipelajari. Sedangkan dengan pemahaman, seseorang tidak hanya bisa menghafal sesuatu yang dipelajari, tetapi juga memunyai kemampuan untuk menangkap makna dari sesuatu yang dipelajari juga mampu memahami konsep dari pelajaran tersebut.

\section{Pengertian Pendidikan Agama}

Untuk memudahkan pemahaman tentang pengertian pendidikan agama, maka terlebih dahulu perlu dijelaskan pengertian pendidikan dan pengertian agama secara umum. Menurut Daradjat, pendidikan dalam bahasa Arabnya adalah tarbiyah dengan kata kerja rabba. Kata kerja rabba yang artinya mendidik sudah digunakan pada zaman Nabi. Dalam bentuk kata benda, kata rabba ini juga digunakan untuk Tuhan, karena Tuhan juga bersifat mendidik, mengasuh, memelihara, bahkan mencipta. Kata lain yang mengandung arti pendidikan adalah addaba dan allama. ${ }^{13}$

Pendidikan berasal dari kata "didik", mendapat awalan "me-", sehingga menjadi "mendidik", yang artinya memelihara dan memberi latihan. Dalam 
memelihara dan memberi latihan diperlukan adanya ajaran, tuntunan, dan pimpinan mengenai akhlak dan kecerdasan pikiran. Pendidikan dapat diartikan sebagai sebuah proses dengan menggunakan metode-metode tertentu, sehingga orang memperoleh pengetahuan, pemahaman, dan cara bertingkah laku yang sesuai dengan kebutuhan. Dalam pengertian yang luas dan representatif, pendidikan merupakan "the total process of developing human abilities and behaviors, drawing on almost all life's experiences", yang berarti seluruh tahapan pengembangan kemampuan-kemampuan dan perilaku-perilaku manusia dan juga proses penggunaan hampir seluruh pengalaman kehidupan. Pendidikan diartikan sebagai tahapan kegiatan yang bersifat kelembagaan yang dipergunakan untuk menyempurnakan perkembangan individu dalam menguasai pengetahuan, kebiasaan, sikap, dan sebagainya.

Yunus mengemukakan berbagai pengertian dari para ahli didik dan ahli filsafat mengenai kata pendidikan, yaitu:

1) Menurut Plato, seorang filosof Yunani, pendidikan adalah mengasuh jasmani dan rohani supaya sampai kepada keindahan dan kesempurnaan yang mungkin dicapai.

2) Jules Simin, filosof Perancis, mengemukakan pengertian pendidikan adalah jalan untuk merubah akal menjadi akal yang lain dan mengubah hati menjadi hati yang lain.

3) John Milton, seorang ahli didik dan ahli syair bangsa Inggris, menjelaskan pendidikan yang sempurna adalah mendidik anak-anak supaya dapat melaksanakan segala pekerjaan, baik pekerjaan khusus atau pekerjaan umum dengan ketelitian, kejujuran, dan kemahiran, baik waktu aman atau waktu perang.

4) Menurut Pestalozzi, seorang ahli didik Swiszerland, pendidikan adalah menumbuhkan segala tenaga anak-anak dengan pertumbuhan yang sempurna dan seimbang.

5) Pengertian pendidikan menurut Herbert Spencer, filosof pendidikan bangsa Inggris, adalah menyiapkan manusia supaya hidup dengan kehidupan yang sempurna.

6) James Mill, filosof Inggris, menurutnya, pendidikan adalah menyiapkan seseorang supaya dapat membahagiakan dirinya khususnya, dan orang lain umumnya.

7) Sully, seorang filosof Inggris yang juga ahli didik dan ahli jiwa, pendidikan adalah menyucikan tenaga tabiat anak-anak supaya dapat hidup berbudi luhur, berbadan sehat, serta berbahagia. ${ }^{14}$

Berdasarkan beberapa pengertian di atas, maka dapat disimpulkan bahwa pendidikan adalah usaha orang dewasa secara sadar untuk membimbing dan mengembangkan kepribadian serta kemampuan dasar anak didik baik dalam bentuk pendidikan formal maupun nonformal. ${ }^{15}$ Pendidikan adalah suatu proses yang memunyai tujuan yang biasanya diusahakan untuk menciptakan pola-pola tingkah laku tertentu pada anak-anak atau orang yang sedang dididik. 
Melalui berbagai pengertian di atas, dapat disimpulkan bahwa pendidikan adalah suatu usaha yang dilakukan secara sadar untuk melatih, membimbing, dan mengembangkan segala potensi yang ada dalam diri seseorang melalui suatu proses dengan menggunakan metode-metode tertentu, baik secara formal maupun nonformal, sehingga orang tersebut memperoleh pengetahuan dan pemahaman, membentuk pola tingkah laku tertentu untuk menciptakan kepribadian yang mandiri supaya sampai kepada kesempurnaan yang mungkin dicapai.

Adapun pengertian agama menurut Syaltut, dalam Quraish Shihab, bahwa agama adalah ketetapan-ketetapan Ilahi yang diwahyukan kepada Nabi-Nya untuk menjadi pedoman hidup manusia. ${ }^{16}$ Syaikh Muhammad Abdul Badran berupaya menjelaskan arti agama dengan menunjuk kepada al-Qur'an, bahwa agama adalah hubungan antara makhluk dengan Khaliknya. Hubungan ini diwujudkan dalam sikap batinnya serta tampak dalam ibadah yang dilakukannya dan tercermin pula dalam sikap kesehariannya.

Merujuk pada pengertian pendidikan dan agama yang telah dipaparkan, maka pendidikan agama diartikan sebagai usaha sadar untuk membentuk kepribadian anak didik sesuai dengan ajaran-ajaran Islam secara sistematis melalui bimbingan, pengajaran, atau latihan dalam bentuk formal maupun nonformal.

Berdasarkan pengertian pemahaman dan pendidikan agama seperti diuraikan di atas, maka bila dirangkaikan maka dapat dikatakan bahwa pemahaman pendidikan agama merupakan kemampuan seseorang untuk mempertahankan sesuatu yang dianggap benar, membedakan mana yang termasuk perbuatan baik dan buruk, memberikan contoh yang baik kepada sesama, dapat menerangkan sesuatu hal yang dapat dipahami, dan lain sebagainya. Apabila seseorang telah memahami ajaran agama tersebut, kemudian meyakini dan mengamalkan semua perintah dan menjauhi larangan dari ajaran agama tersebut, maka keyakinannya yang telah menjadi bagian integral dari kepribadiannya itulah yang akan mengawasi segala perbuatannya baik lahir maupun batin.

\section{Pengertian Nilai-Nilai agama}

Nilai adalah sesuatu yang abstrak dan tidak bisa dilihat, diraba, maupun dirasakan dan tak terbatas ruang lingkupnya. Nilai sangat erat kaitannya dengan pengertian-pengertian dan aktifitas manusia yang kompleks, sehingga sulit ditentukan batasannya, karena keabstrakkannya itu maka Darajat mengemukakan bahwa terdapat bermacam-macam pengertian, diantaranya sebagai berikut:

a) Nilai adalah suatu perangkat keyakinan ataupun perasaan yang diyakini sebagai suatu identitas yang memberikan corak yang khusus kepada pola pemikiran, perasaan, keterkaitan maupun perilaku.

b) Nilai adalah suatu pola normatif, yang menentukan tingkah laku yang diinginkan bagi suatu sistem yang ada kaitannya dengan lingkungan sekitar tanpa membedakan fungsi-fungsi bagian-bagiannya.

c) Nilai adalah rujukan dan keyakinan dalam menentukan pilihan. 
d) Nilai merupakan kualitas empiris yang tidak dapat didefinisikan, tetapi hanya dapat dialami dan dipahami secara langsung.

e) Nilai adalah sesuatu yang bersifat abstrak, ideal, bukan benda konkrit, bukan fakta, bukan hanya persoalan benar salah yang menuntut pembuktian empirik, melainkan soal penghayatan yang dikehendaki, disenangi, dan tidak disenangi. ${ }^{17}$

Berdasarkan beberapa pengertian nilai di atas, maka dapat disimpulkan bahwa nilai merupakan sesuatu yang abstrak, ideal, dan menyangkut persoalan keyakinan terhadap yang dikehendaki, dan memberikan corak pada pola pikiran, perasaan, dan perilaku. Dengan demikian, untuk melacak sebuah nilai harus melalui sebuah pemaknaan terhadap kenyataan lain berupa tindakan, tingkah laku, pola pikir, dan sikap seseorang atau sekelompok orang.

Istilah agama berasal dari bahasa Sansekerta yang sama artinya dengan "peraturan". Namun, dalam bahasa kita ada juga yang mengatakan bahwa kalimat agama berasal dari bahasa Sanskerta yang terdiri dari dua suku, yaitu suku kata "a" yang berarti "tidak" dan "gama" yang berarti "kacau". Jadi, apabila disatukan suku kata "a" dan "gama", maka agama berarti "tidak kacau".

Nilai itu sendiri adalah hakikat suatu hal yang menyebabkan hal itu dikejar oleh manusia. Nilai juga berarti keyakinan yang membuat seseorang bertindak atas dasar pilihannya. Nilai-nilai agama menurut Abdullah Darraz bahwa nilai-nilai agama Islam yang utama adalah nilai-nilai akhlaq. ${ }^{18}$ Oleh karena itu, dapat dijelaskan bahwa nilai-nilai agama Islam adalah nilai-nilai akhlaq agama Islam yang bersangkut paut dengan kewajiban seorang hamba kepada Tuhannya. Nilainilai tersebut diperlukan oleh manusia untuk keselamatan dan kebahagiaanya di dunia dan di akhirat.

Dengan demikian, nilai dapat dirumuskan sebagai sifat yang terdapat pada sesuatu yang menempatkan pada posisi yang berharga dan terhormat, yakni bahwa sifat tersebut menjadikan sesuatu itu dicari dan dicintai, baik dicintai oleh satu orang maupun sekelompok orang. Sebagai contoh adalah nasab bagi orang-orang terhormat memunyai nilai yang tinggi, ilmu bagi ulama memunyai nilai yang tinggi, dan keberanian bagi pemerintah memunyai nilai yang dicintai, dan sebagainya. ${ }^{19}$

Madjid (2000: 8), menyatakan bahwa terdapat beberapa macam nilai-nilai agama mendasar yang harus ditanamkan pada seorang anak dan kegiatan menanamkan nilai-nilai pendidikan inilah yang sesungguhnya menjadi inti pendidikan agama. Di antara nilai-nilai yang sangat mendasar itu, ialah: a) iman, b) Islam, c) ihsan, d) taqwa, e) ikhlas, f) tawakkal, dan g) syukur.

a) Iman, yaitu sikap batin yang penuh kepercayaan kepada Tuhan. Masalah iman banyak dibicarakan di dalam ilmu tauhid. Akidah tauhid merupakan bagian yang paling mendasar dalam ajaran Islam, Tauhid itu sendiri adalah mengesakan Allah swt dalam dzat, sifat, af'al, dan beribadah hanya kepada-Nya. Tauhid dibagi menjadi empat bagian, 
yaitu: Ar Rubuubiyah, Al-Uluuhiyah, Al-Asmaa' wa Ash-Shifaat, AlMulkiyah. ${ }^{20}$

1. Ar-Rubuubiyah (keesaan Allah swt sebagai tuhan pencipta), yaitu men-satu-kan Allah swt dalam kekuasaannya. Artinya seseorang meyakini bahwa hanya Allah swt yang menciptakan, memelihara, menguasai dan yang mengatur alam beserta isinya. Tauhid rububiyyah ini bisa diperkuat dengan memperhatikan segala ciptaan Allah swt, baik benda hidup maupun benda mati. Dalam ilmu-ilmu alam, di samping mempelajari fenomena alam, juga dapat sekaligus membuktikan dan menemukan bahwa Allahlah yang mengatur hukum alam yang ada pada setiap benda. Allah swt sebagai pencipta, pelindung, pemberi rejeki, dan pengatur alam semesta tidak akan mungkin diambil alih oleh yang lain. Allah swt memiliki kekuasaan yang mutlak dan tidak ada satupun yang menyainginya. Oleh karena itu, Allah sebagi Rabb wajib untuk diesakan.

2. Al-Uluuhiyah (keesaan Allah swt sebagai tempat mengabdi/ menyembah). Kata ilah secara umum memunyai arti yang disembah, baik kepada yang haq maupun yang bathil. Sedangkan tauhid uluhiyyah merupakan suatu kunci dari kehidupan di bawah naungan tauhid. Mengesakan Allah sebagai ilah memunyai tuntutan bagi yang mengakuinya. Diantara tuntutan tersebut adalah sholat, puasa, zakat, haji, dan menjalankan syari'at Islam. Pada zaman jahiliyah, kaum kafir Quraisy mengakui Allah swt sebagai Rabb tetapi tidak mengakui Allah swt sebagi ilah.

3. Al-asmaa' wa Ash-shifaat (Keesaan Allah swt dalam nama dan sifat). Mengesakan Allah swt yang memiliki nama-nama dan sifat-sifat kesempurnaan adalah mutlak. Tidak ada sedikitpun kekurangan pada Allah swt. Allah swt yang digambarkan dalam nama dan sifatNya seperti dalam 99 nama Allah adalah gambaran kehebatan dan kesempurnaanNya. Oleh karena itu, tidak layak kita mencari tandingan lainnya sebagai pengakuan keberadaan Allah swt.

4. Al-Mulkiyah (keesaan Allah swt sebagai tuhan raja/ penguasa). Tauhid Mulkiyah adalah mengesakan hanya kepada Allah swt saja yang memiliki pemerintahan dan kekuasaan yang meliputi semesta alam.

b) Islam, adalah istilah (sikap berserah diri) yang membawa kedamaian dan kesejahteraan (as salaam) serta dilandasi oleh jiwa yang ikhlas (sincerity). Tasmara (1995: 152). Adapun menurut Muhammad (2008: 25), Islam merupakan kepatuhan seseorang kepada hukum-hukum syariat secara keseluruhan yang telah dibawa oleh junjungan kita Nabi Muhammad saw.

c) Ihsan, yaitu kesadaran yang sedalam-dalamnya bahwa Allah swt senantiasa hadir bersama umatNya dimanapun umatNya berada, sehingga umat Islam senantiasa merasa terawasi. 
d) Taqwa, yaitu sikap yang sadar bahwa Allah swt selalu mengawasi umatNya, sehingga umatNya akan senantiasa berhati-hati dan hanya berbuat sesuatu yang diridhai Allah swt dan senantiasa menjaga diri dari perbuatan yang tidak diridhaiNya.

e) Ikhlas, yaitu sikap murni dalam tingkah laku dan perbuatan seseorang semata-mata demi memperoleh ridla Allah. swt

f) Tawakkal, yaitu sikap senantiasa bersandar kepada Allah swt dengan penuh harapan kepadaNya dan keyakinan bahwa Allah swt akan menolong dalam mencari dan menemukan jalan yang terbaik.

g) Syukur, yaitu sikap penuh rasa terima kasih dan penghargaan atas segala nikmat dan karunia yang tidak terbilang banyaknya. Amalan yang paling Allah swt harapkan dilakukan manusia kepada Tuhannya adalah bersyukur kepadaNya. Jika manusia merasa tidak perlu bersyukur, maka berarti dia telah mengingkari dan tidak mengimani siapa sang pemberi segala nikmat tersebut. Allah swt berfirman dalam QS. Ibrahim/14: 7,

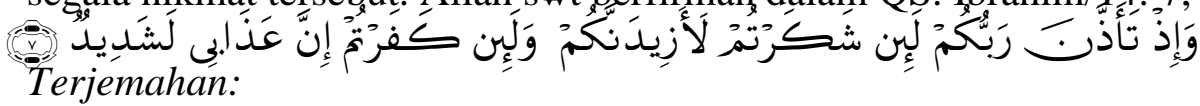

"Dan (ingatlah juga), tatkala Tuhanmu memaklumkan; Sesungguhnya jika kamu bersyukur, pasti Kami akan menambah (nikmat) kepadamu, dan jika kamu mengingkari (nikmat-Ku), Maka Sesungguhnya azab-Ku sangat pedih". (Departemen Agama RI, 2008: 136)

Melalui kesyukuran atas rejeki yang diberikan, maka akan menjadi perbendaharaan yang sangat luas dan berisi segala macam kenikmatan. Sedangkan dengan meremehkan dan tidak mensyukuri rejeki, maka rejeki tersebut akan berubah menjadi satu hal yang sangat tidak diminati manusia.

h) Sabar, yaitu menahan jiwa dalam ketaatan dan senantiasa menjaganya, memupuknya dengan keikhlasan, dan menghiasinya dengan ilmu. Sabar adalah menahan diri dari segala kemaksiatan, dan berdiri tegak melawan dorongan hawa nafsu. Sabar merupakan sikap ridha terhadap qadha dan qadar Allah swt tanpa mengeluh akan yang diberikan kepadanya.

\section{E. Konsep Pengamalan Ibadah}

Masyarakat Islam merupakan masyarakat yang berbeda dengan masyarakat mana pun, baik keberadaannya maupun karakternya. Ia merupakan masyarakat yang Rabbani, insani, akhlaqi, dan masyarakat yang seimbang (tawazun). Ummat Islam dituntut untuk mendirikan masyarakat seperti ini, sehingga mereka bisa memperkuat agama mereka, membentuk kepribadian mereka dan bisa hidup di bawah naungannya dengan kehidupan Islami yang sempurna. Suatu kehidupan yang diarahkan oleh aqidah Islamiyah dan dibersihkan dengan ibadah, dituntun oleh pemahaman yang shahih, digerakkan oleh semangat yang menyala, terikat dengan moralitas dan adab 
Islamiyah, serta diwarnai oleh nilai-nilai Islam. Diatur oleh hukum Islam dalam perekonomian, seni, politik, dan seluruh segi kehidupannya.

Masyarakat Islam bukanlah masyarakat yang hanya menerapkan syari'at Islam pada bidang hukum saja, terutama di bidang pidana dan perdata sebagaimana dipahami oleh mayoritas umat. Yang demikian ini merupakan pemikiran dan praktek yang juz'iyah (parsial), bahkan mengarah pada berbuat dzhalim terhadap masyarakat, dengan memfokuskan seluruh potensi yang bermacam-macam dalam menegakkan satu pilar di antara banyak pilar yaitu hukum, dan bahkan dalam satu bidang saja dari hukum tersebut yaitu pidana atau perdata.

Sesungguhnya asas pertama kali yang tegak diatasnya masyarakat Islam adalah aqidah, itulah aqidah Islam. Maka tugas masyarakat yang pertama adalah memelihara aqidah, menjaga, dan memperkuat serta memancarkan sinarnya ke seluruh penjuru dunia. Aqidah Islam ada pada keimanan kita kepada Allah, malaikatNya, kitab-kitab-Nya, para rasul-Nya, dan hari kemudian, sebagaimana firman Allah swt dalam Q.S.Al-Bagarah/2: 28,5 berikut ini:

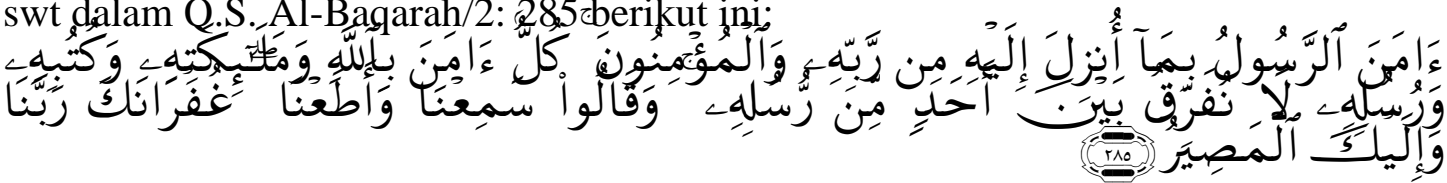

Terjemahnya:

"Rasul telah beriman kepada Al Qur'an yang diturunkan kepadanya dari Rabbnya, demikian pula orang-orang yang beriman. Semuanya beriman kepada Allah, malaikat-malaikat-Nya, kitab-kitab-Nya dan rasul-rasulNya. (Mereka mengatakan): "Kami tidak membeda-bedakan antara seseorang pun (dengan yang lain) dari rasul-rasul-Nya, " dan mereka mengatakan: "Kami dengar dan kami taat," (Mereka berdo'a): "Ampunilah kami wahai Tuhan kami dan kepada Engkaulah tempat kembali." (Departemen Agama RI, 2006: 42)

Aqidah Islam itu membangun bukan merusak, mempersatukan bukan memecah belah, karena aqidah ini tegak di atas warisan ilahiyah seluruhnya dan di atas keimanan kepada para utusan Allah seluruhnya "Laa Nufarriqu Baina Ahadin Min Rusulihi."

Aqidah tersebut diringkas dan dimampatkan dalam syahadatain (dua kalimat syahadat) yaitu: "Asyhaadu an laa ilaaha illallaah wa anna Muhammadan Rasuulullaah." Aqidah inilah yang mempengaruhi pandangan kaum Muslimin terhadap alam semesta dan penciptannya, terhadap alam metafisika, kehidupan ini dan kehidupan setelahnya, terhadap alam yang terlihat dan yang tidak terlihat, terhadap makhluq dan khaliq, dunia dan akhirat, serta terhadap alam yang nampak dan alam gaib (yang tidak kelihatan).

\section{F. Pemahaman Masyarakat tentang Nilai-Nilai Ajaran Islam}

Salah satu tujuan mendasar dari syiar agama yang dilakukan di tengah-tengah masyarakat adalah terciptanya kultur keagamaan yang membumi, dicermati melalui 
penerapan nilai-nilai ajaran agama dalam kehidupan pribadi, rumah tangga, dan bermasyarakat. Kesadaran pendidikan tidak terlepas dari kesadaran pemahaman agama yang utuh, di mana kesadaran dan semangat untuk terus belajar dalam mencari ilmu. Tidak hanya di lembaga formal tapi informal di mana keluarga juga membangun perubahan dan berpartisipasi aktif didalamnya. Sehingga, menjadi makhluk moral spiritual (moral-spiritual-being), yang lebih baik dan bertaqwa kepada sang pencipta.

Pemahaman agama bisa dilihat dalam keluarga awam yang tradisional, di mana aspek intensitas keberagamaan masih minim pula, cara atau metode dalam beragama lebih menekankan pada aspek emosional, pola kelakuan keberagamannya cenderung pada kelakuan lahiriyah (eksoteris) dan sikap dalam beragama kental dengan nuansa trandisional. Faktor penyebab pemahaman agama dipengaruhi oleh beberapa faktor yaitu dari luar dan dari dalam. Dari luar diantaranya ekonomi, sosial, politik, dan budaya. Dari dalam diantaranya dangkalnya ilmu pengetahuan agama, malas beribadah, dan sebagainya. Lebih-lebih faktor dari luar yang kadang sangat mempengaruhinya, sehingga keluarga lebih mementingkan hal-hal yang bersifat materi daripada hal-hal yang bersifat transendental. Kesibukan memenuhi kebutuhan sehari-hari menyebabkan waktu mereka terkuras habis dan kesempatan mempelajari agama kurang, maka keberagamaan mereka lebih bersifat paternalistik (mengandalkan pada figure atau tokoh kunci).

Pemahaman agama disebabkan oleh budaya yang mengangkat pada keluarga setempat di mana peran orang tua memberikan kesempatan kepada kaum muda belajar, tapi semakin banyak orang pintar maka akan menghilangkan budaya setempat misalnya yang dialami keluarga samin, di mana orang tua menyuruh anak-anaknya untuk bersekolah dan menjalankan ibadah agama namun anak tersebut tidak mau menjalankannya, hal ini ada dan benar-benar terjadi.

Pemahaman agama keluarga di Desa Garuntungan pada umumnya masih rendah, sehingga menimbulkan berbagai macam hal yang merugikan bagi keluarga itu sendiri, misalnya jarang melaksanakan shalat, malas shalat berjama'ah ke masjid, tidak aktif dalam pengajian, suka berbuat merugikan orang lain, dan tidak mau bershadaqah. Oleh karena itu, kebanyakan keluarga di Desa Garuntungan menjadi resah akan segala tindakan yang dilakukan oleh orang-orang tersebut.

Pemahaman agama berdampak pada pemahaman akan pentingnya ilmu pengetahuan dan kurangnya penyiapan kader yang berkualitas. Peluang untuk mengenyam pendidikan yang begitu sempit ditambah lagi dengan pengetahuan agama keluarga yang minim, menyebabkan kesadaran keluarga rendah dalam bidang pendidikan, apalagi golongan ekonomi keluarga kebanyakan menengah ke bawah, sehingga tidak mampu menyekolahkan anaknya karena biaya sekolah yang begitu mahal. Hal ini menyebabkan dalam komunitas keluarga yang terjadi hanyalah regenerasi kepada anak turunnya, dididik dengan ilmu yang sama dan kesadaran untuk berkembang atau melakukan perubahan sangatlah lamban.

Pendidikan keluarga didasari oleh adanya hubungan kodrat antara orang tua dan anak serta cinta kasih orang tua terhadap anaknya. Rasa cinta dan kasih sayang 
inilah yang menjadi kekuatan tak kunjung padam pada orang tua yang memberikan bimbingan kepada anaknya agar kelak menjadi manusia dewasa dan berkehidupan yang layak di dunia dan di akhirat kelak.

Keluarga berperan atau menjadi subjek dalam memberikan atau menanamkan kebiasaan pada anak dengan cara yang baik menurut ajaran agama, karena menurut fungsinya keluarga menjadi sarana pendidikan yang pertama kali sebelum anak memasuki usia remaja. Fungsi keluarga sangatlah penting dalam proses pendidikan, karena memang fungsi keluarga sebagai lembaga pendidikan pertama dan utama adalah tempat persemaian pembentukan/penanaman kebiasaan. Adapun yang berperan aktif dalam keluarga yaitu ibu, ayah, anggota keluarga lain, dan diri mereka sendiri, sebagai kunci pendorong agar anak rajin dalam belajar.

Beberapa poin penting yang diselidiki dalam penelitian ini terkait dengan pemahaman nilai-nilai ajaran Islam di dalam masyarakat diuraikan sebagai berikut:

\section{G. Pembahasan Hasil Penelitian}

Penelitian ini dilaksanakan untuk menggambarkan pelaksanaan Nilai-Nilai ajaran Islam pada masyarakat Desa Garuntungan Kecamatan Kindang Kabupaten Bulukumba terhadap nilai-nilai ajaran Islam, serta menjelaskan keterkaitan antara pemahaman nilai-nilai ajaran Islam dengan pelaksanaan nilai-nilai ajaran Islam di Desa Garuntungan Kecamatan Kindang Kabupaten Bulukumba.

Nilai-nilai ajaran Islam yang dimaksud adalah penerapan nilai atau akhlak Islam yang bersangkut paut dengan kewajiban seorang hamba kepada Tuhannya, baik menyangkut ibadah maupun muamalahnya. Ibadah yang dimaksud dapat berupa shalat, zakat, puasa, ataupun haji. Sedangkan muamalahnya adalah terlihat dari hubungan yang terjalin dengan orang lain, misalnya dalam hal jual beli dan sebagainya, serta aktivitasnya dalam kehidupan bermasyarakat. Sebagaimana yang diungkapkan oleh Hasbi ash-Shiddiqy (1994: 27) yang menyatakan bahwa hakikat ibadah adalah ketundukan jiwa yang timbul karena hati (jiwa) merasakan cinta akan Tuhan yang ma'bud (disembah) dan merasakan kebesaran-Nya, lantaran beri'tikad bahwa bagi alam ini ada kekuasaan yang akal tidak dapat mengetahui hakikatnya. Adapun Qardhawi (1998: 43) menyatakan bahwa dalam syari'at Islam, ibadah memunyai dua unsur, yaitu ketundukan dan kecintaan yang paling dalam kepada Allah swt.

Oleh karena itu, dapat dikatakan bahwa ibadah merupakan kewajiban seluruh umat Islam sebagai cerminan nilai-nilai ajaran Islam yang ada pada dirinya. Semakin besar nilai-nilai ajaran Islam yang diterapkan pada dirinya, tentu semakin baik pengamalan ibadahnya dalam kehidupan sehari-hari, dan semakin baik pengamalan ibadah seseorang maka hal tersebut dapat menumbuhkan akhlak yang baik. Apabila dalam sebuah masyarakat diterapkan nilai-nilai ajaran Islam yang baik, maka kehidupan bermasyarakat akan terasa lebih tenang, damai, dan aman.

Pengamalan ibadah seseorang yang mencerminkan pelaksanaan nilai-nilai ajaran Islam dalam kehidupan bermasyarakat tentu dipengaruhi pula oleh pemahaman agama yang dimilikinya. Hal tersebut diungkapkan pula oleh Sudijono (1996: 50) adalah kemampuan seseorang untuk mengerti atau memahami sesuatu setelah sesuatu 
itu diketahui dan diingat. Dengan kata lain, memahami adalah mengetahui tentang sesuatu dan dapat melihatnya dari berbagai segi. Pemahaman merupakan jenjang kemampuan berpikir yang setingkat lebih tinggi dari ingatan dan hafalan. Artinya, pemahaman agama merupakan tingkat mengertinya seseorang terhadap ajaran agama yang dianutnya, baik perintah yang dianjurkan dan larangan Tuhan yang harus dijauhi. Pemahaman agama juga sangat penting dalam pelaksanaan nilai-nilai ajaran Islam dalam suatu masyarakat. Apabilai suatu masyarakat memiliki pemahaman agama yang baik, maka pelaksanaan nilai-nilai ajaran Islam, baik itu sikap Islam, Iman, Ihsan, tawakkal, sabar, bersyukur dan sebagainya dapat diimplementasikan sebaik-baiknya.

Kehidupan masyarakat yang dimaksud dalam penelitian ini adalah kondisi keseharian yang dilakukan oleh masyarakat Desa Garuntungan Kecamatan Kindang Kabupaten Bulukumba yang tercermin dari sikap dan tingkah laku sehari-hari yang teramati oleh orang lain. Menurut beberapa informan yang telah diwawancarai, mereka cenderung menyatakan bahwa sesungguhnya tingkat pemahaman keagamaan masyarakat setempat sudah cukup baik, hanya kemudian terjadi pergeseran akibat perkembangan modernisasi yang didukung oleh majunya teknologi informasi mendorong masyarakat lebih berpikir praktis, hedonis, dan pragmatis.

Keterbatasan ekonomi juga menyebabkan para orang tua tidak mampu membiayai sekolah anaknya yang mengakibatkan anak tersebut tumbuh dalam lingkungan keluarga yang minim akan pendidikan. Ajaran agama juga perlu bimbingan secara khusus seperti halnya dengan pendidikan. Paling tidak, apabila seorang anak sekolah dengan baik, maka anak tersebut juga akan belajar tentang agama. Sehingga anak bisa memperoleh pemahaman akan pentingnya ajaran Islam untuk diterapkan dalam kehidupannya.

Pemahaman pendidikan agama merupakan kemampuan seseorang untuk mempertahankan sesuatu yang dianggap benar, membedakan mana yang termasuk perbuatan baik dan buruk, memberikan contoh yang baik kepada sesama, dapat menerangkan sesuatu hal yang dapat dipahami, dan lain sebagainya. Apabila seseorang telah memahami ajaran agama tersebut, kemudian meyakini dan mengamalkan semua perintah dan menjauhi larangan dari ajaran agama tersebut, maka keyakinannya yang telah menjadi bagian integral dari kepribadiannya itulah yang akan mengawasi segala perbuatannya baik lahir maupun batin.

Pelaksanaan masyarakat Desa Garuntungan akan nilai-nilai Islam pada dasarnya masih relatif baik, walaupun masih sebatas pada ritual-ritual formal keagamaan. Salah satu upaya yang dilakukan untuk meningkatkan pelaksanaan nilainilai keagamaan masyarakat di Desa Garuntungan Kecamatan Kindang Kabupeten Bulukumba adalah melalui kegiatan syiar Islam. Namun, hal tersebut belum berjalan secara optimal.

Masyarakat di pedesaan pada dasarnya menggantungkan hidup dengan hasil pertanian. Kompleksitas masalah yang dihadapi masyarakat di pedesaan (terutama petani tradisional) adalah persoalan dalam memenuhi kebutuhan hidup, terutama yang berkaitan dengan sandang, pangan, dan papan. Masalah lain yang dihadapi 
masyarakat pedesaan adalah pendidikan dan kesehatan. Berbagai persoalan yang melingkari kehidupan masyarakat pedesaan sebagaimana disebutkan di atas tentu akan berimplikasi pada pemahaman dan pengamalan ajaran agama.

Persoalan baru yang dihadapi masyarakat di Desa Garuntungan Kecamatan Kindang Kabupaten Bulukumba adalah "perubahan sosial". Perubahan sosial yang sedang berlangsung saat ini tentu akan memberikan harapan masa depan dan juga akan melahirkan sejumlah problematika, baik secara cepat maupun lambat. Persoalan yang dapat dan mudah kita amati dan rasakan akibat perubahan sosial, salah satunya adalah terjadinya pergeseran nilai dan kepercayaan keagamaan masyarakat. Terlebih masyarakat yang berada pada posisi transisi. Dengan memahami berbagai persoalan yang dihadapi masyarakat di pedesaan, maka materi dakwah (ajaran agama) dan metode penyampaiannya dapat disesuaikan dengan kebutuhan masyarakat setempat, sehingga lebih mudah dimengerti dan diterima masyarakat. Oleh karena itu, pemahaman agama yang masih minim dengan berbagai kendala tersebut menyebabkan pelaksanaan nilai-nilai ajaran Islam di Desa Garuntungan Kecamatan Kindang Kabupaten Bulukumba belum berlangsung secara maksimal.

\section{H. Kesimpulan}

Berdasarkan hasil penelitian dan pembehasan yang telah dipaparkan sebelumnya, maka penulis dapat menyimpulkan beberapa hal mengenai penelitian ini, antara lain:

1. Pemahaman masyarakat Desa Garuntungan akan nilai-nilai Islam pada dasarnya masih relatif baik, walaupun masih sebatas pada ritual-ritual formal keagamaan. Hal ini terlihat kondisi umum yang terlihat di Desa Garuntungan dan diperkuat oleh pernyataan informan yang menilai bahwa sesungguhnya tingkat pemahaman keagamaan masyarakat cukup baik, hanya kemudian terjadi pergeseran akibat perkembangan modernisasi yang didukung oleh majunya teknologi informasi mendorong masyarakat lebih berpikir praktis, hedonis, dan pragmatis.

2. Pemahaman nilai-nilai ajaran Islam masyarakat di Desa Garuntungan sangat terkait erat dengan pelaksanaannya dalam kehidupan sehari-hari masih dapat dikatakan kurang baik. Hal ini disebabkan oleh nilai-nilai agama tidak terimplementasikan dengan baik dalam kehidupan pribadi, keluarga dan masyarakat. Telah terjadi pergeseran perilaku akibat perkembangan modernisasi. Hal ini dapat dilihat dari fenomena lapangan didukung oleh pernyataan informan yang mengakui bahwa masyarakat lebih sibuk dengan pekerjaannya sehingga waktu-waktu pelaksanaan ibadah formal sudah mulai terganggu, jamaah masjid semakin berkurang atau tidak bertambah, pelaksanaan ritual keagamaan lain juga kian jarang dilakukan, terbatasnya orang-orang yang peduli dalam mengurus umat juga semakin kurang. Keadaan tersebut sesungguhnya menggambarkan bahwa tingkat pemahaman nilai-nilai keagamaan relatif baik tetapi pelaksanaannya sulit dilakukan karena terbatasnya waktu karena masyarakat disibukkan dengan urusan dunianya. Hal yang mempengaruhi terjadinya pergeseran perilaku 
Penerapan Nilai-nilai Ajaran Islam dalam

masyarakat dalam pelaksanaan nilai-nilai ajaran Islam di Desa Garuntugan Kecamatan Kindang Kabupaten Bulukumba meliputi pengaruh lingkungan, kesibukan masyarakat, kurangnya siraman rohani (intensitas dakwah), kurangnya pengawasan orang tua terhadap anak, dan pemikiran masyarakat yang lebih memikirkan untuk mencari kerja dibanding mencari ilmu serta mengutamakan pendidikan.

\section{Endnotes:}

${ }^{1}$ Waridkhan Achmad, Memajukan Pendidikan Islam Menuju Masyarakat Madani (Jakarta: Buana Karya, 2002), h. 175)

${ }^{2}$ Zamroni Pembinaan Keluarga Islami (Solo: Tiga Serangkai, 2001), h. 8.

${ }^{3}$ Fasli Jalal, Kebijakan Pendidikan Nasional (Jakarta: Pustaka Utama, 2001), h. 181.

${ }^{4}$ Harefa Andrias, Membangun Masyarakat Islami (Yogyakarta: Pareta Cipta 2003), h. 371. 2009), h. 73.

${ }^{5}$ Muctarom Zaini, Problematika Ibadah dalam Kehidupan Manusia (Jakarta: Kalam Mulia

${ }^{6}$ Muhammad Thalib, Pembinaan Remaja Islam Membangun Bangsa (Jakarta: Pustaka Utama, 1998), h. 192. 2006), h. 53

${ }^{7}$ Suharsimi Arikunto, Prosedur Penelitian Suatu Pendekatan Praktik (Jakarta: Rineka Cipta,

${ }^{8}$ W.J.S. Poerwadarminta, Kamus Umum Bahasa Indonesia (Jakarta: Balai Pustaka, 1991), h. 636.

${ }^{9}$ M. Ngalim Purwanto, Prinsip-Prinsip dan Teknik Evaluasi Pengajaran (Bandung: PT Remaja Rosdakarya, 1997), h. 44. h. 50 .

${ }^{10}$ Anas Sudijono, Pengantar Evaluasi Pendidikan (Jakarta: PT Raja Grafindo Persada, 1996),

${ }^{11}$ Saifuddin Azwar, Tes Prestasi (Yogyakarta: Liberty, 2007), h. 62.

${ }^{12}$ W. S. Winkel, Psikologi Pengajaran (Jakarta: PT Gramedia, 1996), h. 246.

${ }^{13}$ Zakiah Daradjat, Ilmu Pendidikan Islam (Jakarta: Bumi Aksara, 1992), h. 25. 2000), h. 5.

${ }^{14}$ Mahmud Yunus, Pokok-Pokok Pendidikan dan Pengajaran (Jakarta: PT Hidakarya Agung,

${ }^{15}$ H.M. Arifin, Hubungan Timbal Balik Pendidikan Agama di Lingkungan Keluarga (Jakarta: Bulan Bintang, 2004), h. 24.

${ }^{16}$ M. Quraish Shihab, Membumikan Al-Qur'an (Bandung: Mizan, 1994), h. 209-210.

${ }^{17}$ Zakiah Daradjat, Ilmu Pendidikan Islam, h. 260. 
${ }^{18}$ Hasan Langgulung, Manusia dan Pendidikan, Suatu Analisis Psikologi dan Pendidikan (Jakarta: Pustaka al-Husna, 1995), h. 38

${ }^{19}$ Rohmat Mulyana, Mengartikulasikan Pendidikan Nilai (Bandung: Alfabeta, 2004), h. 47.

${ }^{20}$ Irwan Prayitno, Kepribadian Muslim (Jakarta: Mitra Grafika, 2005), h. 180-182.

\section{Daftar Pustaka}

Achmad, Waridkhan. Memajukan Pendidikan Islam Menuju Masyarakat Madani. Jakarta: Buana Karya, 2002.

Andrias, Harefa. Membangun Masyarakat Islami. Yogyakarta: Pareta Cipta. 2003.

Arifin, H. M. Hubungan Timbal Balik Pendidikan Agama di Lingkungan Keluarga, Jakarta: Bulan Bintang, 2004.

Arikunto, Suharsimi. Prosedur Penelitian Suatu Pendekatan Praktik, Jakarta: Rineka Cipta. 2006.

Ash-Shiddiqy, Hasbi. Kuliah Ibadah: Ibadah Ditinjau dari Segi Hukum dan Hikmah, Jakarta: Bulan Bintang, 1994.

Awaluddin. Implikasi Pemahaman Nilai-Nilai Islam terhadap Suasana Kemasyarakatan di Kabupaten Takalar. Tesis Tidak Dipublikasikan. Makassar: Pascasarjana UIN, 2008.

Azwar, Saifuddin. Tes Prestasi. Yogyakarta: Liberty, 2007.

Balikwan, Hanif. Kepemimpinan Orang Tua dalam Pembentukan Pribadi Muslim pada Remaja di Kelurahan Sukoharjo. Tesis Tidak Dipublikasikan. Malang: Pascasarjana UIN Malang, 2000.

Daradjat, Zakiah. Ilmu Pendidikan Islam. Jakarta: Bumi Aksara, 1992.

Departemen Agama RI. Al-Qur'an dan Terjemahannya, Jakarta: PT Toha Putra, 2006.

Jalal, Fasli. Kebijakan Pendidikan Nasional. Jakarta: Pustaka Utama, 2001.

Langgulung, Hasan. Manusia dan Pendidikan, Suatu Analisis Psikologi dan Pendidikan, Jakarta: Pustaka al-Husna, 1995. 
Penerapan Nilai-nilai Ajaran Islam dalam

Madjid, Nurcholish. Masyarakat Religius Membumikan Nilai-Nilai Islam dalam Kehidupan Masyarakat. Jakarta: Pustaka Al-Kautsar, 2000.

Muhammad, Sayyid bin Salim bin Hafidz. Fiqih \& Tasawuf Wanita Muslimah. Surabaya: Cahaya Ilmu, 2008.

Mulyana, Rohmat. Mengartikulasikan Pendidikan Nilai. Bandung: Alfabeta, 2004.

Poerwadarminta, W.J.S. Kamus Umum Bahasa Indonesia, Jakarta: Balai Pustaka, 1991.

Prayitno, Irwan. Kepribadian Muslim. Jakarta: Mitra Grafika, 2005.

Priyantoro, Dian Eka. Strategi Pendidikan Islam dalam Keluarga di Kelurahan Karang Asem Kecamatan Laweyan Kodya Surakarta. Tesis Tidak Dipublikasikan. Malang: Pascasarjana UIN Malang, 2002.

Purwanto, M. Ngalim. Prinsip-Prinsip dan Teknik Evaluasi Pengajaran, Bandung: PT Remaja Rosdakarya, 1997.

Qardhawi, Yusuf. Implementasi Ibadah Islam untuk Keluarga Sakinah. Jakarta: Balai Pustaka, 1998.

Shihab, M. Quraish. Membumikan Al-Qur'an, Bandung: Mizan, 1994.

Sudijono, Anas. Pengantar Evaluasi Pendidikan, Jakarta: PT Raja Grafindo Persada

Tasmara, Toto. Etos Kerja Pribadi Muslim. Yogyakarta: PT Dana Bhakti Wakaf, 1995.

Thalib, Muhammad. Pembinaan Remaja Islam Membangun Bangsa. Jakarta: Pustaka Utama, 1998.

Winkel, W. S. Psikologi Pengajaran, Jakarta: PT Gramedia, 1996.

Yunus, H. Mahmud. Pokok-Pokok Pendidikan dan Pengajaran, Jakarta: PT Hidakarya Agung, 2000.

Zaini, Muctarom, Problematika Ibadah dalam Kehidupan Manusia, Jakarta: Kalam Mulia, 2009.

Zamroni. Pembinaan Keluarga Islami. Solo: Tiga Serangkai, 2001. 